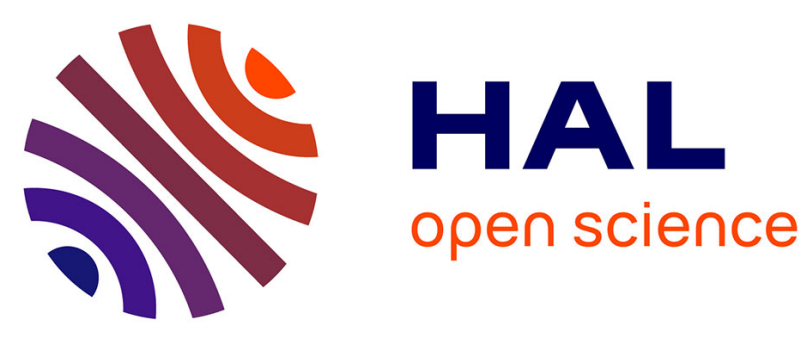

\title{
MO CVD of Noble Metals
}

\author{
I. Igumenov
}

\section{To cite this version:}

I. Igumenov. MO CVD of Noble Metals. Journal de Physique IV Proceedings, 1995, 05 (C5), pp.C5489-C5-496. 10.1051/jphyscol:1995556 . jpa-00253918

\section{HAL Id: jpa-00253918 https://hal.science/jpa-00253918}

Submitted on 1 Jan 1995

HAL is a multi-disciplinary open access archive for the deposit and dissemination of scientific research documents, whether they are published or not. The documents may come from teaching and research institutions in France or abroad, or from public or private research centers.
L'archive ouverte pluridisciplinaire HAL, est destinée au dépôt et à la diffusion de documents scientifiques de niveau recherche, publiés ou non, émanant des établissements d'enseignement et de recherche français ou étrangers, des laboratoires publics ou privés. 


\title{
MO CVD of Noble Metals
}

\author{
I.K. Igumenov
}

Institute of Inorganic Chemistry, Lavrentieva 3, 630090 Novosibirsk, Russia

\begin{abstract}
The state of the art in research and application of processes of chemical vapour deposition of noble metal (Pt, Pd, Rh, Ir, Ru, Au) coatings is considered. Systematization of known experimental data on synthesis, thermal properties and saturated vapour pressure of volatile compounds of noble metals with organic ligands is provided. The processes of CVD of noble metals were analized from general requirements to precursors. It is shown that chelate or mixed-ligand noble metal complexes and, in particular $\beta$-diketonate derivatives due to their thermal properties are the most suitable for deposition of noble metal thick films.
\end{abstract}

\section{INTRODUCTION}

Due to the unique set of physical and chemical properties of noble metals new areas of their applications have recently appeared. Besides, high cost and shortage of the resources of noble metals make the substitution of bulk metal item for the coated one economically warranted. The examples are: the elaboration of heat-resistant coatings for the protection of instrumentation in the processes of glass founding [1], the protection of trust chamber of rocket engines [2], etc.

Particularly these and other problems can be solved using the processes of MO CVD of noble metals. In our opinion, the main difficulties preventing the commercial application of noble metal MO CVD processes are the low rates of coating growth and the lack of suitable precursors. The latter is mainly connected with the insufficient information on the thermal behavior of precursors. The data on the investigation of coating growth processes and the properties of noble metal coatings are also not enough. The review [3] and monographs [4-6] do not make up this lack. In present article the current state of above problems is considered

\section{PRECURSORS FOR MO CVD OF NOBLE METALS}

\subsection{Volatile compounds of noble metals}

The term "volatile compound" is used for characterization of the compounds of metals with organic ligands which can be evaporated at atmospheric or reduced pressure at the temperatures lower then $400 \mathrm{C}$. The range of temperatures $400-500^{\circ} \mathrm{C}$ is also the upper limit of thermal stability of metal complexes with organic ligands in condensed phase (with the several exceptions). Volatile compounds of noble metais with organic ligands of different types used for the preparation of MO CVD films and the compounds for which direct or indirect infomation on volatility is known are presented in Table 1.

The main types of noble metal compounds (shown in Table 1) with considerable saturated rapour pressure values at medium temperatures can be conventionally divided in three groups containing metal-carbon bond. chelate complexes and mixed-ligand compounds 
Table 1: Volatile compounds of noble metals

\begin{tabular}{|c|c|c|c|c|c|}
\hline $\mathbf{P t}$ & Pd & Ir & $\mathbf{R h}$ & $\mathbf{R u}$ & Au \\
\hline \multicolumn{6}{|c|}{ Homoligand carbonyls } \\
\hline & & $\operatorname{lr}_{4}(\mathrm{CO})_{12}$ & $\begin{array}{l}{\left[\mathrm{Rh}(\mathrm{CO})_{3}\right]_{\mathrm{n}}} \\
\mathrm{Rh}_{4}(\mathrm{CO})_{12}\end{array}$ & $\mathrm{Ru}(\mathrm{CO})_{5}$ & \\
\hline \multicolumn{6}{|c|}{ Heteroligand carbonyls } \\
\hline $\begin{array}{l}\mathrm{Pt}(\mathrm{CO})_{2} \mathrm{Cl}_{2} \\
\mathrm{Pt}(\mathrm{CO})_{2} \text { (aa) }\end{array}$ & & $\begin{array}{l}\operatorname{Ir}(\mathrm{CO})_{3} \mathrm{X} \\
\operatorname{Ir}(\mathrm{CO})_{2} \mathrm{Cl}_{2} \\
\operatorname{Ir}(\mathrm{CO})_{2}(\mathrm{aa}) \\
\operatorname{Ir}(\mathrm{CO})_{2} \mathrm{~L}^{n} \\
\operatorname{Ir}(\mathrm{CO})_{2}(\mathrm{Cp})\end{array}$ & $\begin{array}{l}{\left[\mathrm{Rh}(\mathrm{CO})_{2} \mathrm{Cl}\right]_{2}} \\
{\left[\mathrm{Rh}(\mathrm{CO})_{2} \mathrm{~F}_{3}\right]_{2}} \\
\mathrm{Rh}(\mathrm{CO})_{2}(\mathrm{aa}) \\
\mathrm{Rh}(\mathrm{CO})_{2} \mathrm{~L}^{\mathrm{n}(\mathrm{s})}\end{array}$ & $\begin{array}{l}\mathrm{Ru}(\mathrm{CO})_{2} \mathrm{Cl}_{2} \\
\mathrm{Ru}(\mathrm{CO})_{3} \mathrm{I} \\
\mathrm{Ru}(\mathrm{CO})_{2} \mathrm{Br}\end{array}$ & $\mathrm{Au}(\mathrm{CO}) \mathrm{Cl}$ \\
\hline \multicolumn{6}{|c|}{ Cyclo(penta)dienyl compounds } \\
\hline $\begin{array}{l}\left(\mathrm{CH}_{3}\right)_{3} \mathrm{Pt}(\mathrm{Cp}) \\
\left(\mathrm{CH}_{3}\right)_{3} \mathrm{Pt} *(\mathrm{MeCp})\end{array}$ & $\begin{array}{l}(\mathrm{COD}) \mathrm{Pd}(\mathrm{Cp}) \\
\left(\mathrm{C}_{10} \mathrm{H}_{12}\right) \mathrm{Pd} * \\
\left(\mathrm{OCH}_{3}\right)_{3}(\mathrm{Cp})_{2}\end{array}$ & $\begin{array}{l}\text { (COD)Ir(aa) } \\
(\mathrm{Cp}) \operatorname{Ir}(\mathrm{Cp})\end{array}$ & $\begin{array}{l}\text { (COD)Rh(hfa) } \\
\text { (dien)Rh(aa) } \\
\text { (dien)Rh(Cp) }\end{array}$ & $\begin{array}{l}\mathrm{Ru}(\mathrm{Cp})_{2} \\
(\mathrm{COD}) \mathrm{Ru}(\mathrm{CO})_{3} \\
(\mathrm{dien})_{\mathrm{x}} \mathrm{Ru}(\mathrm{CO})_{\mathrm{y}} \\
(\mathrm{Cp}) \mathrm{Ru}(\mathrm{CO})_{2} \mathrm{H} \\
{\left[\left(\mathrm{Ru}(\mathrm{CO})_{2}(\mathrm{Cp})\right]_{2}\right.}\end{array}$ & \\
\hline \multicolumn{6}{|c|}{ Allyl complexes } \\
\hline $\begin{array}{l}\left(\mathrm{C}_{3} \mathrm{H}_{5}\right)_{2} \mathrm{Pt} \\
\left.\left[\mathrm{C}_{3} \mathrm{H}_{5}\right)_{2} \mathrm{Pt}(\mathrm{aa})\right]_{2} \\
\left(\mathrm{MeC}_{3} \mathrm{H}_{4}\right) \mathrm{Pt}(\mathrm{aa}) \\
\left(\mathrm{C}_{3} \mathrm{H}\right)_{5} \mathrm{Pt}(\mathrm{Cp})\end{array}$ & $\begin{array}{l}\left(\mathrm{C}_{3} \mathrm{H}_{5}\right) \mathrm{Pd} \\
\left(\mathrm{MeC}_{3} \mathrm{H}_{4}\right)_{2} \mathrm{Pd} \\
{\left[\left(\mathrm{C}_{3} \mathrm{H}_{5}\right) \mathrm{PdX}\right]_{2}} \\
\left(\mathrm{C}_{3} \mathrm{H}_{5}\right)_{2} \mathrm{Pd}(\mathrm{aa}) \\
\left(\mathrm{C}_{3} \mathrm{H}_{5}\right) \mathrm{Pd}(\mathrm{Cp}) \\
\end{array}$ & $\left(\mathrm{C}_{3} \mathrm{H}_{5}\right)_{3} \mathrm{Ir}^{*}$ & $\begin{array}{l}\left(\mathrm{C}_{3} \mathrm{H}_{5}\right)_{3} \mathrm{Rh} \\
\left(\mathrm{C}_{3} \mathrm{H}_{5}\right)_{2} \mathrm{Rh}(\mathrm{Cp}) \\
\left(\mathrm{C}_{3} \mathrm{H}_{5}\right)_{2} \mathrm{Rh}(\mathrm{aa})\end{array}$ & $\left(\mathrm{C}_{3} \mathrm{H}_{5}\right)_{2} \mathrm{RuCO}_{2}$ & \\
\hline \multicolumn{6}{|c|}{ Olefin complexes } \\
\hline $\begin{array}{l}\left(\mathrm{C}_{2} \mathrm{H}_{4}\right)_{2} \mathrm{Pt} \\
\left(\mathrm{C}_{2} \mathrm{H}_{4}\right) \mathrm{Pt}(\mathrm{COD})\end{array}$ & $\left(\mathrm{C}_{2} \mathrm{H}_{4}\right)_{2} \mathrm{Pd}$ & $\begin{array}{l}\left(\mathrm{C}_{2} \mathrm{H}_{4}\right)_{2} \operatorname{Ir}(\mathrm{aa}) \\
\left(\mathrm{C}_{2} \mathrm{H}_{4}\right)_{2} \operatorname{Ir}(\mathrm{Cp})\end{array}$ & $\begin{array}{l}\left(\mathrm{C}_{2} \mathrm{H}_{4}\right)_{2} \mathrm{Rh}(\mathrm{aa}) \\
\left(\mathrm{C}_{2} \mathrm{H}_{4}\right)_{2} \mathrm{Rh}(\mathrm{Cp})\end{array}$ & & \\
\hline \multicolumn{6}{|c|}{ Phosphine compounds } \\
\hline $\mathrm{P} 1\left(\mathrm{PF}_{3}\right)_{4}$ & & $\operatorname{Ir}\left(\mathrm{PF}_{3}\right)_{4}$ & $\mathrm{Rh}\left(\mathrm{PF}_{3}\right)_{4}$ & & $\begin{array}{l}\mathrm{R}_{3} \mathrm{PAuCl} \\
\mathrm{R}_{3} \mathrm{AsAuCl} \\
\left(\mathrm{CH}_{3}\right)_{7} \mathrm{Au} * \mathrm{PMe}_{3} \\
\mathrm{CH}_{3} \mathrm{AuPEt}_{3}\end{array}$ \\
\hline \multicolumn{6}{|c|}{ Other compounds } \\
\hline $\begin{array}{l}\operatorname{cis}-\left(\mathrm{CH}_{3}\right)_{2} \mathrm{Pt*} \\
\left(\mathrm{CH}_{3} \mathrm{NC}_{2}\right. \\
\mathrm{Pt}(\mathrm{aa})_{2} \mathrm{I}_{2}\end{array}$ & & $\begin{array}{l}(\mathrm{Cp}) \operatorname{Ir}\left(\mathrm{PMe}_{3}\right) * \\
\left(\mathrm{C}_{2} \mathrm{H}_{4}\right) \\
\text { dimetoryiridium }\end{array}$ & $\begin{array}{l}(\mathrm{Cp}) \mathrm{Rh}(\mathrm{PMe})_{3}{ }^{*} \\
\left(\mathrm{C}_{2} \mathrm{H}_{4}\right)\end{array}$ & {$\left[\mathrm{Ru}(\mathrm{CO})_{4} \mathrm{SiMc}_{3}\right]_{2}$} & $\begin{array}{l}\mathrm{CF}_{3} \mathrm{AuCH}_{3} \mathrm{NC} \\
\mathrm{C}_{8} \mathrm{H}_{20} \mathrm{Au}_{2} \mathrm{P}_{2}\end{array}$ \\
\hline \multicolumn{6}{|c|}{ Chelate complexes } \\
\hline $\begin{array}{l}{\left[\left(\mathrm{CH}_{3}\right)_{3} \mathrm{Pt}(\mathrm{aa})\right]_{2}} \\
\left(\mathrm{CH}_{3}\right)_{3} \mathrm{PtL} \mathrm{f}_{\star} \mathrm{H}_{2} \mathrm{O} \\
(\mathrm{Py}) \\
\mathrm{Pt}(\mathrm{aa})_{2} \\
\mathrm{Pt}(\mathrm{hfa})_{2} \\
\mathrm{PtLf} \mathrm{f}_{2} \\
\mathrm{Pt}\left(\mathrm{ktf}_{2}\right. \\
\mathrm{Pt}\left(\mathrm{S}_{2} \mathrm{PF}_{2}\right)_{2} \\
\mathrm{PtL} \mathrm{fs}_{2}\end{array}$ & $\begin{array}{l}\operatorname{Pd}(\mathrm{aa})_{2} \\
\mathrm{Pd}(\mathrm{hfa})_{2} \\
\mathrm{PdL} \mathrm{f}_{2} \\
\mathrm{Pd}(\mathrm{ktf})_{2} \\
\mathrm{Pd}(\mathrm{Xan})_{2} \\
\mathrm{Pd}\left(\mathrm{Xan}_{2}\right)_{2} \\
\mathrm{Pd}\left(\mathrm{S}_{2} \mathrm{PF}_{2}\right)_{2} \\
\mathrm{PdL} \mathrm{fs}_{2}\end{array}$ & $\begin{array}{l}\operatorname{Ir}(\mathrm{aa})_{3} \\
\operatorname{IrL} f_{3} \\
\operatorname{Ir}\left(R_{2} d t c\right)_{3}\end{array}$ & $\begin{array}{l}\operatorname{Rh}(\mathrm{aa})_{3} \\
\operatorname{RhL}_{3} \\
\operatorname{RhL}_{3} \mathrm{fs}_{3} \\
\operatorname{Rh}\left(\mathrm{S}_{2} \mathrm{PF}_{2}\right)_{3} \\
\operatorname{Rh}\left(\mathrm{R}_{2} \mathrm{dic}\right)_{3}\end{array}$ & $\begin{array}{l}\operatorname{Ru}(a a)_{3} \\
\operatorname{RuL}_{3}\end{array}$ & $\begin{array}{l}\left(\mathrm{CH}_{3}\right)_{2} \mathrm{Au}(\mathrm{aa}) \\
\left(\mathrm{CH}_{3}\right)_{2} \mathrm{Au}(\mathrm{dpm}) \\
\left(\mathrm{CH}_{3}\right)_{2} \mathrm{AuL} \\
\left(\mathrm{CH}_{3}\right)_{2} \mathrm{AuL}^{\mathrm{fs}} \\
\left(\mathrm{CH}_{3}\right)_{2} \mathrm{Au}^{*} \\
\left(\mathrm{R}_{2} \mathrm{dtc}\right)\end{array}$ \\
\hline
\end{tabular}

Abbreviations: X- halide; Me-methyl; aa - acetylacetonato; tfa - trifluoroacetylacetonato; hfa hexafluoroacetylacetonato; dpm - dipivaloylmethanato; $L^{f}$ - fluorinated $\beta$-diketonato; $L^{n}$ iminoketiminato; $L^{f s}$ - mono-thio-fluorinated i-diketonato; ktf - trifluoroketiminato; Xan xantogenato, Xan ${ }^{f}$ - fluorocontaining xantogenato; Cp-cyclopentadienyl; (OD-cyclooctadienyl: $R$, dtc-dithiocarbamato. 
Necessary but insufficient condition of sublimation of the compound at low temperatures is that it has to possess a molecular structure. Actually, complexes with molecular structure can be polymers (oligomers), can include not only organic ligands, but others, for example, acidoligands. The formation of these complexes is characteristic feature of noble metals. It is connected with their behavior in the reaction mixture as well as with the specific properties of ligands. The oligomers are less volatile and thermally stable.

\subsection{General requirements for precursors}

At present the choice of precursors for CVD is carried out according to the following parameters:

1) volatility of the compound (dependence of vapour pressure on temperature);

2) thermal stability in condensed phase;

3) thermal stability in gas phase;

4) possibility to control the decomposition temperature and film growth rate by addition of gas-reagent;

5) constancy of properties in time and tolerance to external influences (moisture, air oxygen);

6) untoxicity;

7) inertness of the construction materials to the decomposition products and precursors;

8) possibility of synthesis of the precursors with high yield

These properties can be divided in two groups including fundamental properties and a set of technological parameters necessary for the successful application of the precursors in MO CVD processes. The most important requirements in the choice of precursor are the requirements determining thermal properties.

\section{THERMAL PROPERTIES OF PRECURSORS}

\subsection{Vapour pressure}

The dependence of saturated vapour pressure on temperature is the quantitative characteristic of the compounds volatility. Sublimation and evaporation of metal complexes are classified as phase transitions of the first type and are described by Clauzius-Clapeiron equation:

$$
\mathrm{dp} / \mathrm{dT}=\Delta \mathrm{H} / \mathrm{T} \Delta \mathrm{v}
$$

where $\Delta H$ is an enthalpy of the phase transition under the equilibrium; $\Delta v$ is a difference between molar volumes of phases; $T$ is a temperature, $p$ is pressure.

Proceeding from the above assumptions we obtain:

$$
\ln p=-\Delta H / R T+\Delta S / R
$$

where $L S$ is a change of the entropy upon the formation of 1 mole of gas during phase transition.

The agreed-upon equation for the temperature dependence of saturated vapour pressure is:

$$
\text { In } p=B-A T, B=\Delta S / R, A=\Delta H / R
$$

The most part of the results on measurements of saturated vapour pressure for volatile compounds of platinum metals have been obtained by different variants of static method $[7,8]$, flow method [9] and Knudsen's method $[10]$ as well.

As a rule only the parameters of the processes of compound isolation from reaction mixture and its purification by sublimation (distillation) are known for noble metal complexes. The systematic investigation of volatility of noble metal complexes was carried out only for p-diketonates of Pt [9], Pd [7, 11], Ir [12], Rh [7, 12], Ru [13], Au [14]. The pronounced dependence of vapour pressure on ligand substituent type is observed for platinum metal 13 -diketonates as well as for other metals. For example, in acetylacetone ligand the substitution of methyl radicals for the trifluoromethyl ones results in 3-4 order increase of vapour pressure $[7,8]$. The analogous effect was obtained upon the variation of olefin ligands $(\mathrm{L})$ in the complexes of $\mathrm{M}(\mathrm{CO})_{2} \mathrm{~L}$ type, where $\mathrm{M}-\mathrm{Rh}$. Ir [10]. The nature of intermolecular interactions and correlation between volatility molecular and crystal sructures of these complexes are reported in $[15-17]$.

Typical temperature dependencies of vapour pressure for three different classes of platinum conpounds with

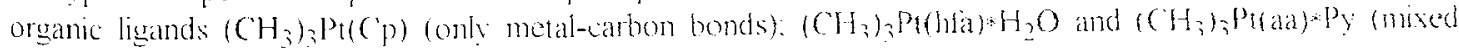


complexes); $\mathrm{Pt}(\mathrm{aa})_{2}, \mathrm{Pt}(\mathrm{ktf})_{2}$ and $\mathrm{Pt}(\mathrm{hfa})_{2}$ (chelate complexes) are given in Fig. 1. At the temperature of $100{ }^{\circ} \mathrm{C}$ the given compounds possess the following values of vapour pressure:

$\left(\mathrm{CH}_{3}\right)_{3} \mathrm{Pt}(\mathrm{Cp})-3.72$ Torr (extrapolation), $\quad\left(\mathrm{CH}_{3}\right)_{3} \mathrm{Pt}(\mathrm{hfa}) * \mathrm{H}_{2} \mathrm{O}-4.00$ Torr (extrapolation), $\left(\mathrm{CH}_{3}\right)_{3} \mathrm{Pt}(\mathrm{aa}) * \mathrm{Py}-0.066$ Torr (extrapolation), $\mathrm{Pt}(\mathrm{ktf})_{2}-0.011$ Torr (extrapolation),

Pt(hfa $)_{2}-1.39$ Torr.

Thus, at $100^{\circ} \mathrm{C}$ the mixed complex $\left(\mathrm{CH}_{3}\right)_{3} \mathrm{Pt}(\mathrm{hfa}) * \mathrm{H}_{2} \mathrm{O}$ has the highest value of vapour pressure among the above volatile platinum complexes. At the same time, the value of $\mathrm{Pt}(\mathrm{hfa})_{2}$ (chelate complex) vapour pressure is 20 times higher than that of $\left(\mathrm{CH}_{3}\right) \mathrm{Pt}(\mathrm{aa}) * \mathrm{Py}$ (mixed complex). Upon the increase of temperature the consequence of the volatility of the complexes changes. It is only possible to suggest with high degree of probability that metalorganic compounds of platinum metals possess higher vapour pressure values than that of mixed complexes which, in tum, are more volatile than chelate derivatives. The conclusion demands the special analysis in each case because, for example for metal $\beta$-diketonates, the pressure can change 4 orders [18].

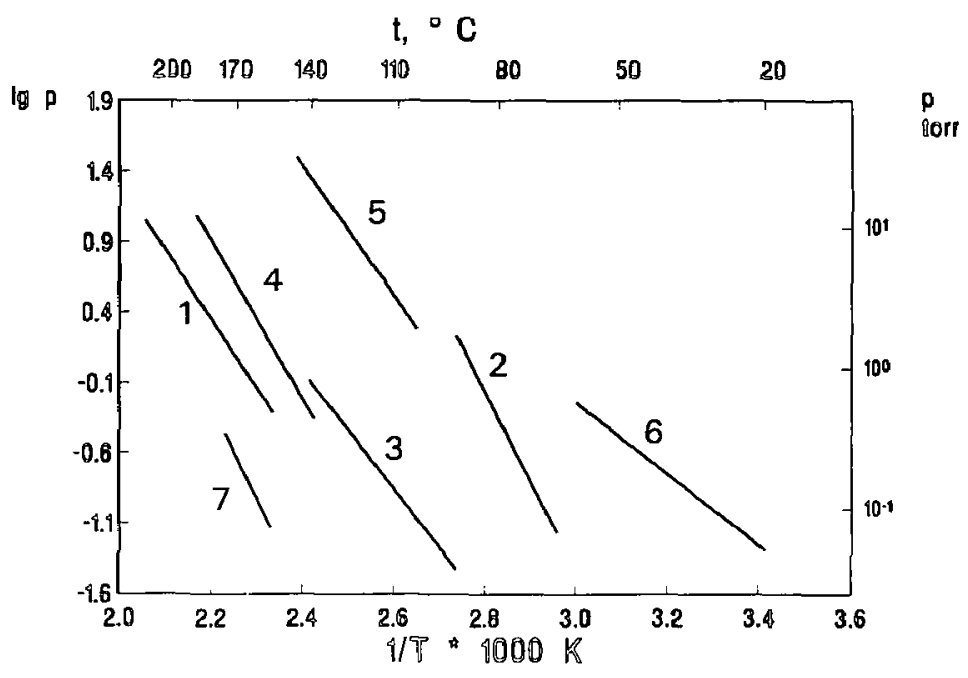

Figure 1: Vapour pressure of some platinum complexes.

$\mathrm{Pt}(\mathrm{ktf})_{2}(1),\left(\mathrm{CH}_{3}\right)_{3} \mathrm{Pt}(\mathrm{hfa}) \cdot \mathrm{H}_{2} \mathrm{O}(2),\left(\mathrm{CH}_{3}\right)_{3} \mathrm{Pt}(\mathrm{aa}) \cdot \mathrm{Py}$ (3), cis-Pt(tfa) $)_{2}$ (4), $\mathrm{Pt}(\mathrm{hfa})_{2}$ (5), $\mathrm{CpPtMe}_{3}$ (6), $\mathrm{Pt}(\mathrm{aa})_{2}$ (7).

\subsection{Thermal stability in condensed state}

There is no information on investigation of thermal behavior of volatile metalorganic compounds of noble metals in condensed state. For platinum metal mixed-ligand compounds and chelates the data on thermal properties of complexes are known only for $\beta$-diketonate derivatives. The analysis data allow to make the following conclusions concerning the change of thermal stability in condensed state for a set of platinum metal $\beta$ diketonates [11, 19-21].

1. For all ligands under investigation iridium(III) $\beta$-diketonates are found to be most thermally stable. The complexes can be arranged in the following row of thermal stability depending on the nature of central atom:

$$
\mathrm{Ir}(\mathrm{III})>\mathrm{Rh}(\mathrm{III})>\mathrm{Ru}(\mathrm{III})>\mathrm{Pt}(\mathrm{II})>\mathrm{Pd}(\mathrm{II})>\mathrm{Au}(\mathrm{III}) \text {. }
$$

2. The data on dependence of thermal stability on end substituent in the ligand is less ambiguous. The complexes with dipivaloylmethane are the most stable. As a rule, the onset decomposition temperature for the fluorinated s-diketonates was found to be lower than that for other complexes in cases when it was possible to determine mentioned temperature. According to the data obtained one can artange the following row of thermat stability of platinum metal $\beta$-diketonates depending on the ligand nature

$$
\text { dpm }>\text { aa }>\text { tfa } \cdots \text { hfa. }
$$


Thermal behavior of platinum metal 1 -diketonates in the active and inert atmosphere is quite different (Table 2). When the reducing medium is used the additional problems connected with the high sensitivity of platinum and especially palladium compounds to hydrogen arise

The systematic investigations of thermal behavior of the mixed compounds were carried out only for complexes of trimethylplatinum [22] and dimethylgold with $\beta$-diketonate [23] and some thio- and iminoanalogues [24].

The type of substituent in ligand and nature of donor molecule in complexes of trimethylplatinum with $\beta-$ diketonate determine almost all peculiarities of thermal behaviour of this class of compounds. Substitution of water for pyridine results in the essential increase of thermal stability of the complexes slightly decreasing their volatility in the case of fluorinated ligands. Pyridine adducts of trimethylplatinum $\beta$-diketonates have higher decomposition temperatures in hydrogen atmosphere too. However, in general, the homoligand platinum (II) $\beta-$ diketonates are essentially more stable than the mixed-ligand platinum (IV) complexes

Complexes of gold are less stable to heating. Slight increase of thermal stability of mixed gold complexes can be achieved by substitution of $\beta$-diketonate ligand for enaminoketone [24]. The reducing atmosphere does not influence on the decomposition temperature of gold complexes under investigation.

\subsection{Thermal stability in gas phase}

The thermal decomposition of volatile complex vapour on heated surface (gas phase thermal stability) was carried out for separated $\beta$-diketonate complexes of Pt and Pd [14], Rh and Ir [20], Au [25] and Ru [26]

The thermal properties of precursor vapor were investigated by flow method. The construction of a thermal reactor combined with mass spectrometer is described in details in $[14,27]$. Its construction is similar to a twotemperature variant of double chamber Knudsen cell. Some results for a number of noble metal complexes are given in Table 2. The study of processes of thermal decomposition of gaseous palladium $\beta$-diketonates has shown that onset thermal decomposition temperatures increase regularly upon the consequent substitution of methyl radical for trifluoromethyl ones in ligand. The row of thermal stability in the gas phase is reverse to the row of thermal stability in the solid state.

Table 2: Onset decomposition temperatures $\left(\mathrm{T}_{\text {dec }}\right)$ of mixed and chelate complexes of noble metals in gas and condensed phase.

\begin{tabular}{|c|c|c|c|c|c|c|}
\hline \multirow[t]{2}{*}{ Compound } & \multicolumn{6}{|c|}{ Onset decomposition temperature, $T_{\mathrm{dec}} \cdot 10^{\circ} \mathrm{C}$} \\
\hline & vacuum & $\mathrm{D}_{2}$ & $\mathrm{O}_{2}$ & $\mathrm{He}$ & $\mathrm{H}_{2}$ & $\mathrm{O}_{2}$ \\
\hline $\operatorname{Rh}(\mathrm{aa})_{3}$ & 395 & 405 & 200 & 303 & 300 & 244 \\
\hline $\operatorname{Ir}(\mathrm{aa})_{3}$ & 405 & 410 & 225 & 350 & 310 & 252 \\
\hline $\operatorname{Ir}(\mathrm{hfa})_{3}$ & 465 & 445 & 300 & -- & - & -- \\
\hline $\operatorname{Pd}(\mathrm{aa})_{2}$ & 305 & 150 & -- & 210 & 20 & - \\
\hline $\mathrm{Pd}(\mathrm{hfa})_{2}$ & 380 & $>20$ & - & 172 & 20 & - \\
\hline $\mathrm{Pt}(\mathrm{hfa})_{2}$ & 345 & 175 & - & 180 & 50 & - \\
\hline$\left(\mathrm{CH}_{3}\right)_{3} \mathrm{Pt}(\mathrm{tfa}) \cdot \mathrm{H}_{2} \mathrm{O}$ & -- & - & - & 114 & 54 & - \\
\hline$\left(\mathrm{CH}_{3}\right)_{3} \mathrm{Pt}(\mathrm{tfa}) \cdot \mathrm{Py}$ & -- & -- & - & -- & 155 & - \\
\hline$\left(\mathrm{CH}_{3}\right)_{2} \mathrm{Au}(\mathrm{aa})$ & 92 & 56 & - & 145 & 125 & - \\
\hline$\left(\mathrm{CH}_{3}\right)_{2} \mathrm{Au}(\mathrm{tfa})$ & 70 & 45 & - & 140 & 125 & $\therefore$ \\
\hline$\left(\mathrm{CH}_{3}\right)_{2} \mathrm{Au}(\mathrm{dpm})$ & 125 & -- & - & 200 & 160 & - \\
\hline
\end{tabular}


The data obtained for other noble metal complexes evidence in the fact that isolated molecules decompose at sufficiently higher temperatures than that for complexes in condensed state. The values of onset decomposition temperature of compound vapour can be used for the optimization of the parameters of noble metal films deposition.

\section{MO CVD PROCESSES FOR NOBLE METALS AND PROPERTIES OF COATINGS}

The precursors should be evaluated according to their tolerance to external influences and time during which the compound can hold its physical chemical properties. Sensitivity to moisture, oxygen, etc. is individual characteristic of the compounds and depends on the metal nature. However, in general, chelate complexes are more tolerant to external influences. These complexes hold their parameters upon storage for a long time.

\subsection{Carbonyl derivatives}

A limited number of examples of use of homoligand platinum metal carbonyls as precursors are known [3]. That is connected with low thermal stability of the compounds and their high sensibility to external influences. Carbonylhalogenides of these metals are more stable than carbonyls, exept palladium compounds. They are used for preparation of metal coatings in CVD processes. The isolation of metals from carbonylhalogenides proceeds at relatively high temperature $500-600^{\circ} \mathrm{C}$. At such temperature severe corrosion of apparatus by decomposition products are observed. The films contain high quantity of carbon. The use of reducing medium allows to diminish the film deposition temperature and to decrease the carbon content [28].

\subsection{Cyclopentadienyl derivatives}

From the compounds of this class $\mathrm{Ru}(\mathrm{Cp})_{2}$ is common use for deposition of ruthenium films [3]. The volatile heteroligand platinum and palladium compounds containing both dien ligand and allyl or methyl are used for preparation of metal films [3]. The deposition temperatures of Pt and Pd films are moderate and range from 250 to $300^{\circ} \mathrm{C}$ in vacuum. The use of hydrogen as gas-reagent allows to decrease the decomposition temperature of platinum films to $120-180^{\circ} \mathrm{C}$, and to diminish the carbon content to 1 at. $\%$ [29]. Other impurities were not detected in platinum films. The film specific resistivity was found to be around $26 \Omega \cdot \mathrm{cm}$.

\subsection{Allyl compounds}

The application of homoligand allyl complexes for the deposition of Pt [30], Pd [20], Ir [31] and Rh [31] films is known. The deposition temperature of $\mathrm{Rh}$ and Ir films at atmospheric pressure in the presence of hydrogen is $120^{\circ} \mathrm{C}$. Platinum and palladium are deposited at $250^{\circ} \mathrm{C}$ in vacuum.

\subsection{Olefin complexes}

Tris(ethylene)palladium [32] as well as tris(ethylene)platinum is a highly volatile compound. They are stable only in ethylene and give a pure palladium metal film in the absence of ethylene.

\subsection{Phosphine compounds}

The method of platinum deposition using tetrakis(trifluorophosphine)platinum $\mathrm{Pt}\left(\mathrm{PF}_{3}\right)_{4}$ was proposed $[33,34]$. At the thernolysis of $\mathrm{Pt}\left(\mathrm{PF}_{3}\right)_{4}$ the uniform smooth continuous adherent thin films of mirror-bright platinum on a variety of substrates are formed under optimum deposition conditions. The preferred ambient is hydrogen. The 
preferred temperature range is $200-300^{\circ} \mathrm{C}$. A deposition rate of $50-100 \mathrm{~A} / \mathrm{min}$ is the most convenient. Platinum contains some amount of residual phosphorus that was found to be non-uniformly distributed. Adherence to insulators was comparable to that of active metals such as aluminium or titanium.

Hydrolysis of the compound by air moisture resulting in platinum, $\mathrm{H}_{3} \mathrm{PO}_{4}, \mathrm{HF}$ and some amount of phosphorus-containing impurities as well as a low deposition rate can limit the use of trifluorophosphine platinum complex for CVD of thick platinum layers at atmospheric pressure. The use of $\mathrm{Pt}\left(\mathrm{PF}_{3}\right)_{4}$ as precursor for thermal decomposition under effusive flow conditions results in films with high purity and uniformity. The volatile gold phosphine compounds are used for the deposition of gold films [35].

\subsection{Mixed-ligand and other compounds}

Mixed-ligand complexes containing $\beta$-diketone ligands are used for deposition of films of all noble metals. The introduction of $\beta$-diketone ligand, as a rule, substantially increases the tolerance to external influence and thermal stability of complex in condensed state. The nature of metal in precursor does not influence in carbon content in films deposited without reaction agents.

\subsection{Chelate complexes}

Among the volatile chelate complexes of noble metals presented in Table 1 only metal $\beta$-diketonates were used for CVD processes. The films deposited in vacuum at high temperatures from acetylacetonate complexes contain carbon impurities. The use of various reaction agents allows to decrease carbon content [36].

Among the volatile noble metal compounds with organic ligands the chelate complexes have the highest thermal stability. It is characterized for $\beta$-diketonate derivatives and their imine analogues. The chelate derivatives are considerably more stable to external influences because all coordination sites are occupied. These complexes are stable upon storage for a long time. For example, in our experiments some iridium compounds did not change their properties for 3-4 years without any special conditions.

Total analysis of the data on vapour pressure and thermal properties has indicated that $\beta$-diketonates with trifluoromethyl groups in ligands appear to be the most suitable precursors due to their appropriate volatility and thermal stability in gas and condensed phases. This conclusion is mainly related to platinum and palladium complexes.

\section{CONCLUSION}

At present the processes of chemical deposition from gas phase using the volatile complexes of noble metals with organic ligands are perspective for the elaboration of resource-saving technologies. The use of noble metals in CVD-processes allows to produce multilayer and multicomponent coatings with high adhesion for one technological cycle.

\section{References}

[1] Coupland P.D., Platimum Metals Rev. 2 (1993) 62-70

[2] Hamilton J.C., Yang N.Y.C. and Clift W.M., Met. Trons. 23A (1992) 851-855.

[3] Rubezhov A.Z., Platimum Metals Rev. 36 (1992) 26-29.

[4] Organometalic chemistry methods. Types of transition metal organometallic compounds (Nauka Moscow, 1975) p. 687 (in Russian)

[5] Chemistry of the platinum group metals: Recent developments (Ed. by Hartley F.R., Elsevier Science Publishers. Amsterdam, 1991)642 p. 
[6] Syrkin V.G., Metal carbonyls (Khimiya, Moscow, 1983) 200 p (in Russian).

[7] Wolf W.R., Sievers R.E. and Brown G.H., Inorg. Chem. 11 (1972) 1995-1999.

[8] Chumachenko Yu.V., Igumenov I.K. and Zemskov S.V., Izv. Sib. Otd. Acad. Nouk SSSR, Ser. Khim. 6 (1979)

10-16 (in Russian).

[9] Zharkova G.I., Igumenov I.K. and Zemskov S.V., Koord. Khim. 9 (1983) 845-850 (in Russian).

[10] Esse A.C., Ernsting J.M. and Stufkens D.F., Thermochim. Acta. 25 (1978) 69-77.

[11] Zharkova G.I., Igumenov I.K. and Tyukalevskaya N.M., Koord. Khim. 14 (1988) 67-74 (in Russian).

[12] Isakova V.C., Igumenov I.K. and Zemskov S.V., Koord. Khim. 11 (1985) 1377-1380 (in Russian).

[13] To be published

[14] Semyannikov P.P., Ph.D. Thesises (Inst. of Inorg. Chem., Novosibirsk, 1988) (in Russian).

[15] Stabnikov P.A., Igumenov I.K., Belosludov V.R. et al., Iz7. SO AN SSSR, Ser.Khim.Nauk. 2 (1985) 37-42 (in Russian).

[16] Belosludov V.R., Stabnikov P.A. and Igumenov I.K., Izv. SO AN SSSR, Ser.Khim.Nauk. 12 (1988) 7-14 (in Russian).

[17] Belosludov R.V., Igumenov I.K., Belosludov V.R. et al., Mol. Physics 82 (1994) 51-66.

[18] Igumenov I. K., Chumachenko Yu.V. and Zemskov S.V., in: Problems of chemistry and application of metal $\beta-$ diketonates (Nauka, Moscow, 1982) pp. 100-120 (in Russian).

[19] Zharkova G.I., Igumenov I.K., Tkachev S.V. et al., Koord. Khim. 8 (1982) 74-78 (in Russian).

[20] Isakova V.G., Semyanikov P.P., Grankin V.M.et al., Koord. Khim. 14 (1988) 57-62 (in Russian).

[21] Morozova N.B., Mit'kin V. N, Igumenov I.K et al., Koord. Khim. 15 (1989) 110-115 (in Russian).

[22] Zharkova G.I., Igumenov I.K. and Zemskov S. V., Koord. Khim. 5(1979) 743-748 (in Russian).

[23] Zharkova G.I., Igumenov I.K. and Zemskov S. V., Koord. Khim. 6 (1980) 720-723 (in Russian).

[24] Zharkova G.I., Tyukalevskaya N.M., Igumenov I.K. et al., Koord. Khim. 14 (1988) 1362-1367 (in Russian).

[25] Semyannikov P.P., Zharkova G.I., Grankin V.M. et. al., Metalloorg. Khim. 1 (1988) 1105-1112 (in Russian).

[26] To be published

[27] Bykov A.F., Semyannikov P.P.and Igumenov I. K., J. Therm. Anal. 38 (1992) 1477-1486.

[28] Rand M.J., J. Electrochem. Soc. 120 (1973) 686-689.

[29] Chen Y.-J., Kaesz H.D., Thridandam H. et al., Appl. Phys. Lett. 53 (1988) 1591-1598.

[30] Gozum J.E., Pollina D.M., Jensen J.A. et al., J. Amer. Chem. Soc. 110 (1988) 2688-2690.

[31] Kaesz H.D., Williams R.S., Hicks R.F. et al., New J. Chem. 14 (1990) 527-531.

[32] Green M., Howard J.A.K., Spenser J.L. et al., J. Chem. Soc., Dalton Trans. (1977) 271-272.

[33] Rand M.J., J. Electrochem. Soc: 122 (1975) 811-815.

[34] Morabito J.M.and Rand M.J., Thin Solid Films. 22 (1974) 293-297.

[35] Patent U.S. 2,847,319.

[36] Gel'fond N.V., Igumenov I.K., Boronin A.I. et al., Surf. Sci. 275 (1992) 323-331. 